\title{
Study on the influence of advertising attractiveness on the purchase decisions of women and men
}

\author{
Fatimah Furaji \\ University of Basrah, Iraq \\ fatma9_74@yahoo.com \\ Małgorzata Łatuszyńska \\ Szczecin University, Poland \\ mlat@wneiz.pl \\ Agata Wawrzyniak \\ Szczecin University, Poland \\ agataw@wneiz.pl \\ Barbara Wąsikowska \\ Szczecin University, Poland \\ barbara.wasikowska@wneiz.pl
}

\begin{abstract}
This article attempts to document differences in purchase decisions of men and women. Earlier research has found that they, due to their different upbringing and socialization along with various other social, biological and psychological factors, depict different types of consumer behaviour. The purpose of this study is to investigate the influence of advertising attractiveness on male and female purchase decisions. The aim of the paper is to present the authorial research procedure which proposes the usage of the theory of rough set to determine the rules of the consumers' behaviour. Implications and directions for future research are provided on the basis of the results.
\end{abstract}

Received: September, 2013

1st Revision:

October, 2013

Accepted: November, 2013

DOI:

$10.14254 / 2071-$ $8330.2013 / 6-2 / 2$

Keywords: consumer behaviour, purchase decision making, advertising, rough set theory.

JEL classification: D1, M3.

\section{INTRODUCTION}

Knowledge of the issues concerning the purchasers' behaviour in the market is an extremely important, and even essential, element in the creation of the modern enterprise marketing strategy. The ability to predict the consumers' response and to identify determinants of their decision-making processes, and the knowledge of to what extent the consumers are brand sensitive (and other forms of marketing impact 
of the manufacturer on the market) largely determine the entrepreneur's success (Wiśniewska, 2005). The consumer's choice is a result of a complex play of cultural, social, personal and psychological factors (Table 1). The complexity of the system of these factors perfectly illustrates the model of the consumer's behaviour called the black-box model (Figure 1). Putting the majority of the types of factors in the table 1, it shows the relations between external stimuli, consumer's traits, the decision-making process and the consumer's response expressed through his or her choices.

Table 1

Types of Factors Affecting Consumer Buying Behaviour

\begin{tabular}{|l|l|}
\hline \multicolumn{1}{|c|}{ Researcher } & \multicolumn{1}{c|}{ Major factors } \\
\hline Zikmond and Amico (1993) & social factors, environmental factors, individual factors \\
\hline McCarthy and Perreault (1993) & physical factors, social factors \\
\hline Narayyana and Raol (1993) & physical factors, social factors, culture factors \\
\hline Keegan (1995) & social factors, culture factors, economic factors, geography factors \\
\hline Setlow (1996) & personal factors, marketing mix, environmental factors \\
\hline Stanton (1997) & social factors, physical factors, attitudinal factors \\
\hline Lancaster and Reynold (1998) & physical factors, social factors, culture factors \\
\hline Kotler and Armstrong (2007) & physical factors, social factors, culture factors, personal factors \\
\hline Straughan and Roberts (1999) & demographic factors, lifestyle \\
\hline Pride and Ferrell (2000) & social factors, physical factors, attitudinal factors \\
\hline Kardes, Cline and Cronley (2011) & $\begin{array}{l}\text { personal factors, attitudinal factors, cognitive factors, physical factors, } \\
\text { culture factors, social factors }\end{array}$ \\
\hline Rudnicki (2012) & $\begin{array}{l}\text { psychological factors, personal-demographic factors, socio-cultural } \\
\text { factors, economic factors }\end{array}$ \\
\hline
\end{tabular}

Source: own elaboration based on Stávková et al., 2008; Suleiman, 2000; Obaidat, 1995; Kardes et al., 2011;

Rudnicki, 2012.

\begin{tabular}{|c|c|c|c|c|}
\hline & Stimuli & Black Box of & isumer Behaviour & Reaction \\
\hline & $\begin{array}{l}\text { Marketing mix } \\
-\quad \text { Product } \\
-\quad \text { Price } \\
- \text { Place } \\
\text { - Promotion } \\
\text { Other } \\
-\quad \text { Demographic } \\
-\quad \text { Economic } \\
-\quad \text { Social } \\
-\quad \text { Cultural } \\
-\quad \text { Technical } \\
-\quad \text { Geographic }\end{array}$ & $\begin{array}{l}\begin{array}{l}\text { Consumer } \\
\text { features }\end{array} \\
- \text { Attitudes } \\
- \text { Needs } \\
-\quad \text { Life style } \\
-\quad \text { Personality } \\
- \text { Perception }\end{array}$ & $\begin{array}{ll}\text { Decision-making } \\
\text { process } \\
-\quad \text { Needs } \\
\text { recognition } \\
-\quad \text { Information } \\
\text { search } \\
-\quad \text { Alternate } \\
& \text { evaluation } \\
- & \text { Purchase } \\
& \text { decision } \\
- & \text { Post-purchase } \\
& \text { behavior }\end{array}$ & $\begin{array}{l}\text { Purchase } \\
-\quad \text { Product } \\
-\quad \text { Brand } \\
-\quad \text { Seller } \\
-\quad \text { Amount } \\
-\quad \text { Payment } \\
\text { No purchase }\end{array}$ \\
\hline
\end{tabular}

Figure 1. The Black Model of Consumer Behaviour

Source: own elaboration based on Keegan et al., 1992; Kotler et al., 2002. 
One of the most crucial factors influencing the consumer's choice, according to the black-box model, is the marketing mix, which includes the promotion. The key element of the promotional activities is advertising, defined as "any paid form of non-personal presentation and promotion of ideas, goods and services by an identified sponsor" (see Kotler, 1994, p.574; Ayanwale et al., 2005; Bovee et al., 1995). The major aim of advertising is to create positive attitude towards the advertisement and the brand until a consumer purchases that product and through this positive attitude create emotional response in the mind of a consumer (Goldsmith and Lafferty, 2002). Advertising is the element that directly influences marketing processes, and above all, motifs, attitudes and behaviours of purchasers (Altkorn, 1998, p. 6-10). As a promotional strategy, advertising serves as a major tool increasing product awareness in the mind of a potential consumer to make an eventual purchase decision (Latif and Abideen, 2011, cited by: Abideen and Saleem, 2011).

The issue of making the purchase decision under the influence of the advertisement has been repeatedly discussed in literature. A number of publications provide the results of the study on the advertising efficiency, but none of them includes the differences resulting from the consumers' gender (e.g. Niazi, 2012; Fu1 and Chen, 2012; Abideen and Saleem, 2011; Ayanwale et al., 2005). Of course, this does not mean that the issue of differences in making decisions by women and men is omitted. Several works prove it, for example those by María L. Sanz de Acedo Lizárraga, María T. Sanz de Acedo Baquedano and María Cardelle-Elawar (2007). Similar studies were made in Malaysia by S. Mokhlisi and H. S. Salleh (2009). Another studies also prove that the purchase decisions may be gender dependent (e.g. Bakshi, 2012; Rudell and College, 1993; Bae and Lee, 2011).

However, so far the results of the studies on the influence of the advertising on the decisions made by women and men have seldom been published. The aim of this article is to make up for this deficit. Here are presented the results of the study on the influence of advertising attractiveness on the purchase decisions of women and men in the market of electrical devices. Empirical data crucial for the study to be made were gathered via questionnaire survey. The aim of the article is to present the authorial research procedure which proposes the usage of the rough set theory to determine the rules of the consumers' behaviour.

\section{PURCHASE DECISION MAKING OF WOMEN AND MEN}

As it was mentioned in the introduction, the process of decision making is one of the most complex mechanisms of the human thinking, as various factors and courses of action intervene in it with different results. Orasanu and Connolly (1993) define it as a series of cognitive operations performed consciously, which include the elements from the environment in a specific time and place. Narayan and Corcoran-Perry (1997) consider decision making as the interaction between a problem that needs to be solved and a person who wishes to solve it within a specific environment. In the classic theory of decisions, decision making means a group of logically connected mental operations or calculations, leading to the solution of a decision problem through the choice of one out of all possible variants of behaviour.

As with other psychological phenomena, sex and age are among the variables that affect decision making, or rather, that allow one to establish individual differences. The fact is that decisions are affected by beliefs about the characteristics that differentiate the genders, although those beliefs may be based on questionable criteria. Despite the fact that society is progressing towards social and labour equality between men and women, it is necessary to continue to examine from a psychological perspective whether there are sex differences in the importance that people allocate to factors that determine the decision process. Till now, the results of research are somewhat ambiguous because, although some significant differences have been identified, most of them are minimal (Crow et al., 1991; Hatala and Case, 2000; Hawkins and Power, 
1999; Venkatesh, Morris, \& Ackerman, 2000; cited by: Sanz de Acedo Lizárraga et al., 2007). It seems that women are more affected by the environment; they look for more information, and dedicate more time to the decision process (Gill et al., 1987; cited by: Sanz de Acedo Lizárraga et al., 2007). Men, on the contrary, are more dominant, assertive, objective, and realistic (Wood, 1990; cited by: Sanz de AcedoLizárraga et al., 2007). However, these differences have been interpreted as the result of the incidence of sex-related social norms and stereotypes that are transmitted in the form of values, traditions, and behavioural expectations. Together with some other educational factors, these probably foment and maintain some of the differences associated with certain aspects of decisions (Bussey and Bandura, 1999; cited by: Sanz de AcedoLizárraga et al., 2007). Therefore, although utill now the findings have been somewhat limited, it is relevant to continue to investigate these differences and determine how they are formed.

Understanding the consumers' purchase decision-making process allows marketers to gain more knowledge about their consumers. Moreover, it can be a foundation for them to create more suitable marketing strategies for their target consumers. If marketers understand this process of their consumers, they will know how their consumers search for information before buying, which criteria can encourage them to purchase, and what factors influence their purchase decision-making. (Solomon et al., 2010; cited by: Bakshi, 2012). Studies suggest that customers generally go through a five-stage decision-making process whenever they make a purchase. This is summarised in figure 2. The model implies that customers pass through all of the stages in every purchase.

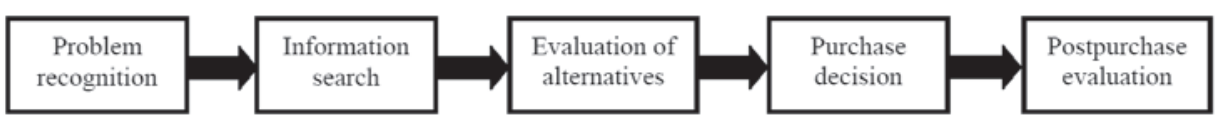

Figure 2. Consumer Buying Decision Process

Source: Furaiji F., Łatuszyńska M., Wawrzyniak A., 2012, p. 80.

Consumption has always been gendered. Most of the products made these days have a specific gender type, some have masculine features and some have feminine features ascribed to them. Products' genders are created and sustained by marketers. Different researches suggest that shopping is a more exciting activity for women than for men. Female consumers feel more independent when they do shopping in accordance with men. Another evidence that men and women present differentiation is that women consider shopping as a social need whereas male consumers pay importance to main function of a product instead of a secondary function. Gender plays an important role in the consumer behaviour because the differences between menand women about expectation, want, need, life-style etc. reflect to their consumption behaviour (Bakshi S., 2012, p. 5). Men and women due to their different upbringing and socialization along with various other social, biological and psychological factors depict different types of behaviour in various situations.

Men and women traditionally approach the purchase decisions very differently. The dissimilarity results from men and women wanting different things being an effect of a buying decision. Women look for satisfying long term needs and wants while men are short-sighted and look for satisfying immediate or short term needs and wants (Baker, 2012). Traditionally, the purchase decision is to move from customer's awareness to interest in purchasing and finally narrowing of options (Kraft and Weber, 2012).

As per a research by Davis and Rigaux (1974) women were found to be dominant during the problem recognition and information search stage for "traditional" female products like home furnishing, appliances, cereals etc. whereas their husbands were found to be more dominant in the information search stage for male 
dominated products like cars, TV sets, etc. Gender was identified as a factor influencing information search and other meaningful consumer behaviour constructs. Several broad advertising implications follow the observed gender differences. The specialized hemispheric processing by males suggests that they might benefit from nonverbal reinforcement (e.g. pictures, music etc.) of the verbal product information contained in an advertisement. On the other hand, the more integrated and symmetrical processing by females suggests that verbally descriptive messages might be more useful for such an audience. The rather strongly held gender identities suggest that appropriately targeted gendered advertisements might be quite effective, especially in cultures where there is a strong gender role prescription (Putrevu 2001).

Male and female consumers evaluate messages in advertisements differently. The selectivity model by Joan Meyers-Levy suggests that men and women should exhibit different searching patterns. Men will tend to go to the most salient cue while women will tend to comprehend all information available (Haas, 1979; Meyers-Levy and Maheswaran,1991), females are more subjective, intuitive, comprehensive, and relational processing while men are more logical, analytical, selective and item-specific processing. Males' selectivity and item-specificity predict that they may search less comprehensively than females and focus on certain information sources and topics. When it comes to decision making, women use other people's opinions to help make their own decision while men use other people's decisions to help them form their own opinion.

Additionally, previous researches have shown that though gender plays a vital role there are differential gender roles across products. As it was mentioned above, Davis and Rigaux (1974) did research on the study of family decision-making roles. They found out that the roles and relative influence of men and women differed basing on a decision-making stage and product type. Further, Belch and Willis (2002) argued that the purchase decisions related to the household items such as cars, TV sets and financial services are moving from being primarily male dominated to joint decisions. This may be due to the rising education level and increasing in the number of working women. Studies show that the household decision-making areas that were once dominated by one gender were also becoming more influenced by the opposite gender (Bakshi, 2012).

In conclusion, prior studies provide convicting evidence that the consumers' decision-making styles varies by genders. However, none of these studies have focused on male and female consumers in Iraq. The authors believe that male and female consumers in Iraq may also have certain distinctive characteristics in terms of their decision orientation towards shopping and buying that could be of equal interest to both researchers and marketing practitioners. This study fills this gap by studying the differences in decision-making styles based on gender in the Iraqi context.

\section{THE METHODS USED AND THE PROPOSED RESEARCH PROCEDURE}

One of the basic groups of methods allowing study on the analysis of the consumers' behaviour are surveys. Literature and practice distinguish three elementary kinds of surveys: secondary survey based on secondary sources, and survey research and experimental survey both based on primary sources (a wide overview of the methods of gathering data from secondary and primary sources is included in the works of: Kaczmarczyk, 2003; Kędzior et al., 2005; Pfaff, 2010). The methods of surveys vary in the level of anonymity and control. The review of literature made by the authors shows that the most common method of gathering data in the customers' behaviour studies is questionnaire study (Burns, 2000; Lancaster, 2005; Kaczmarczyk, 2003). This is the reason why the authors decided to choose this method.

Unfortunately, the data from questionnaires cannot provide direct information that could be used in the process of the analysis of the consumers' behaviour. In such a situation, usually a statistical analysis of raw 
empirical data is made and on the basis of it, it is possible to state whether there is any relation between the variables and how strict this relation is. The regression and correlation analysis is one of the most important and commonly used statistical techniques. It is a tool that precisely determines the relations between variables. However, it is essential to pay attention to the fact, that numerical stating of existing relations does not always mean the existence of cause and effect relation between variables (e.g. repeatedly mentioned in the literature on the subject studies of the apparent correlation between the number of occupied stork nests and the number of births in the given area). Co-occurrence of two phenomena can also be a result of being directly influenced by yet another, third phenomenon.

As it shows, the usually used static analysis does not allow full study of cause and effect relationship, which is essential in searching for the rules of behaviour. This is why there is a need to find another methods which would fill the gap. One of such methods is a rough set theory. The rough set theory may be an appropriate tool to process the survey data about the decision rules and types of behaviour of various consumers (Vindigni et al., 2002; Cui, 2009).

The rough set theory was proposed by Zdzisław Pawlak in the beginning of 1980s' (Pawlak, 1982). Since then, it has been developed for many years by the author and other researchers, being the basis of different methods and information tools which enable, among other things, induction of decision rules or reduction of data. The theory of rough set has gained huge popularity and is currently used in: data exploration and knowledge discovery, complex classification tasks, and computer systems of decision support. Areas to which the theory has been applied are, among others: medicine, pharmacology, finances and marketing (above all including the market research), production management, signal and image processing, speech recognition, linguistics, artificial intelligence, chemistry, sociology. The usage is accompanied by the systems and modules. A detailed study of both theoretical background and the list of the usage of the rough set theory can be found in (Komorowski et al., 1999).

Popularity of this method was caused by many factors. Above all, the rough set theory together with algorithms that use it allow to analyse large data sets and this enables reduction of a set of features describing objects to the necessary minimum (so called attributes set reduct), deleting inconsistent data, if there are such, and generating the, so called, minimal rules, which means simulating the behaviour of an expert in a given area, who would usually be able to present his or her knowledge as such rules (using if ... and ... then... structure). Advantages of the theory of rough set are as follow: it does not demand data assumptions (for example probability or fuzziness), it includes fast algorithms for data analysis, it simplifies the process of results interpretation, and it is characterized by considerable mathematical simplicity (Pawlak, 2004).

Because of the above features, this theory may also be applied to marketing research. The last few years resulted in many scientific publications about the usage of the rough set theory in the analysis of consumers' behaviour, for example: Cui (2009), Hyuang (2010), Liou and Tzeng (2010), Ogino et al. (2010), Shibata (2010), Furaiji and Wąsikowska (2012). Preference studies are currently the major area of interest for the researchers in economy and management. These are the basic category of research in modelling the consumers' behaviour in the marker, taking into account the rationality of decision-making.

In order to analyse the data using the rough set method, the data gathered by a researches during, for example, the survey must be recorded in the form of so called primary decision table (see figure 3). A decision table is an ordered five $\mathrm{T}=(\mathrm{U}, \mathrm{Q}, \mathrm{D}, \mathrm{V}, \mathrm{f})$, where $\mathrm{D}$ is a set of characteristics (attributes) of decision-making, $\mathrm{U}$ is a set of objects (examples) and is called the universe, $\mathrm{Q}$ is a set of characteristics (conditional attributes), $\mathrm{V}=\mathrm{Uq} \in \mathrm{Q}$ and $\mathrm{Vq}$ is a set of all possible values of attributes, and $\mathrm{f}: \mathrm{U} \times \mathrm{Q} \rightarrow \mathrm{V}$ is a function of information (Rutkowski, 2005). Representing data in a table has two basic features: universality, which means that is allows gathering and restoring various data, and efficiency, which means that is allows to easily analyse such data in a computer. Data gathered in the primary decision table are analysed according to such steps: 

a) discretisation (encoding) data,
b) studying the importance of particularconditional attributes,
c) reduction of space of conditional attributes (detecting redundant attributes),
d) construction of the rules base,
e) rejection of conflicting rules,
f) simplification of remaining rules (combining similar rules),
g) assessment of quality and accuracy of the received rules,
h) record of the rules in the linguistic form (decoded).

The record of the received rules in the decoded form makes them easy to understand for a decision-maker, who, on the basis of those rules, is to make a decision concerning, for example, the marketing strategy of a company. The rough set method can successfully be applied to practise as an effective analysis tool.

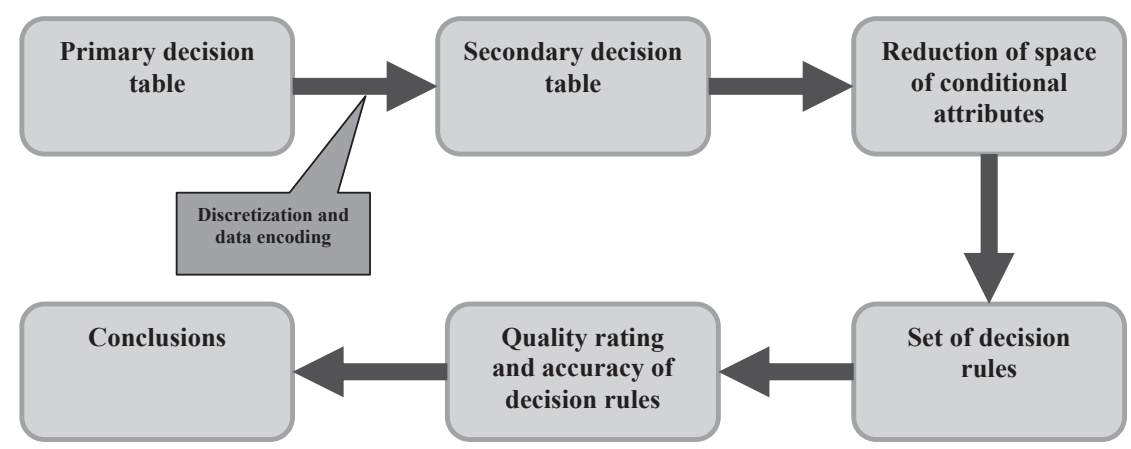

Figure 3. Steps of rough sets modelling

Source: own elaboration based on Wawrzyniak A., 2010.

For the purpose of carrying out the study on the influence of advertising attractiveness on the purchase decisions of women and men, the authorial research procedure has been developed. This procedure proposes usage of the rough set theory in setting the rules of consumers' behaviour. The procedure consists of the following steps:

1. Analysis of historical data concerning the consumers' behaviour in purchasing electrical devices (surveys and static analysis),

2. Construction of the base of consumers' behaviour rules with the usage of the rough set theory,

3. Formulation of conclusions on the basis of the analysis of the rules base.

\section{THE RESULTS}

The article presents the method of applying the rough set theory to the analysis of women's and men's preferences in purchasing electrical devices for their households and the influence of advertising on the decisions concerning the purchase of those devices. The empirical data, crucial for the study, were gathered through surveys. The survey, conducted in December 2011 in Basra (city in the southern Iraq), resulted in 174 correctly filled questionnaires (out of 200 sent ones). The poll included 5 questions concerning age, sex, education, income and the number of people in the family of each respondent and 44 questions concerning 
the purchasing preferences connected to buying home appliances. The last question concerned the issue of advertising attractiveness being the significant factor in purchases made by a respondent (Likert scale: A1 - totally disagree and disagree, A2 - fairly, A3 - agree and totally agree) and whether it is a decisive attribute. The gathered data were collected in the form of a primary information table (Table 2).

Table2

A fragment of the primary information table

\begin{tabular}{|c|c|c|c|c|c|c|c|c|}
\hline & Sex & Age & $\ldots$ & Question 1 & Question 2 & $\ldots$ & Question 43 & Decision attribute \\
\hline p1 & female & $18-24$ & $\ldots$ & fairly & totally disagree & $\ldots$ & totally agree & fairly \\
\hline p2 & female & $45-54$ & $\ldots$ & totally agree & totally disagree & $\ldots$ & totally agree & disagree \\
\hline p3 & female & $18-24$ & $\ldots$ & totally agree & disagree & $\ldots$ & agree & totally agree \\
\hline p4 & female & $18-24$ & $\ldots$ & totally agree & totally agree & $\ldots$ & totally agree & agree \\
\hline p5 & female & $18-24$ & $\ldots$ & totally agree & agree & $\ldots$ & agree & fairly \\
\hline. &. &. &. &. &. &. &. &. \\
. &. &. &. &. &. &. &. &. \\
\hline p170 & male & $25-34$ & $\ldots$ & totally agree & agree & $\ldots$ & totally agree & totallyagree \\
\hline p171 & male & $45-54$ & $\ldots$ & totally agree & disagree & $\ldots$ & agree & agree \\
\hline p172 & male & $35-44$ & $\ldots$ & agree & agree & $\ldots$ & fairly & fairly \\
\hline p173 & male & $35-44$ & $\ldots$ & totally agree & totally agree & $\ldots$ & agree & disagree \\
\hline p174 & male & $35-44$ & $\ldots$ & totally agree & totally agree & $\ldots$ & agree & disagree \\
\hline
\end{tabular}

Source: own elaboration

In the next step, in accordance with the theory of rough set, the data collected in the primary information table went through the process of discretisation and encoding, as a result of which the secondary information table was made (Table 3).

Table 3

A fragment of the secondary information table

\begin{tabular}{|c|c|c|c|c|c|c|c|c|}
\hline & Sex & Age & $\ldots$ & q1 & q2 & $\ldots$ & q43 & d \\
\hline p1 & F & v1 & $\ldots$ & A2 & A1 & $\ldots$ & A3 & A2 \\
\hline p2 & F & v4 & $\ldots$ & A3 & A1 & $\ldots$ & A3 & A1 \\
\hline p3 & F & v1 & $\ldots$ & A3 & A1 & $\ldots$ & A3 & A3 \\
\hline p4 & F & v1 & $\ldots$ & A3 & A3 & $\ldots$ & A3 & A3 \\
\hline p5 & F & v1 & $\ldots$ & A3 & A3 & $\ldots$ & A3 & A2 \\
\hline. &. &. &. &. &. &. &. &. \\
. &. &. &. &. &. &. &. &. \\
. &. &. &. &. &. &. &. &. \\
\hline p170 & M & v2 & $\ldots$ & A3 & A3 & $\ldots$ & A3 & A3 \\
\hline p171 & M & v4 & $\ldots$ & A3 & A1 & $\ldots$ & A3 & A3 \\
\hline p172 & M & v3 & $\ldots$ & A3 & A3 & $\ldots$ & A2 & A2 \\
\hline p173 & M & v3 & $\ldots$ & A3 & A3 & $\ldots$ & A3 & A1 \\
\hline p174 & M & v3 & $\ldots$ & A3 & A3 & $\ldots$ & A3 & A1 \\
\hline
\end{tabular}

Source: own elaboration 
Such pre-prepared data was analysed by the method of rough sets, using the program DAT (Data Analysis Toolbox) operating in MATLAB R2010a. First, an analysis of the data on the buying preferences and the influence of advertising attractiveness on the purchase decisions of women were made, and then of men. In both cases, the introductory analysis was made according to the following steps:

defining elementary sets (sets of examples including the same values of conditional attributes),

defining decisive concepts (sets of examples including the same value of decision)

an attempt to reduce the sets of conditional attributes in both a relative and absolute way.

As a result of the survey, two reducts were obtained. The first reduct is a set of conditional attributes which have the biggest influence on the purchase decisions of women. The second reduct includes those attributes which have the biggest influence on the purchase decisions of men. Both reducts are presented in table 4 together with the significances of particular conditional attributes.

The next step was to approximate the set, meaning determining the lower and upper approximations, boundary, and the positive and negative regions of the set (detailed explanation of this notions and suitable formulas may be found in the works of (Piegat, 2005/2006; Rutkowski, 2005; Mrózek and Płonka, 1999; Wąsikowska 2007).

Table 4

Significance of conditional attributes included in the reducts

\begin{tabular}{|l|c|}
\hline \multicolumn{1}{|c|}{ Reduct 1 Attribute } & Significance \\
\hline \multicolumn{1}{|c|}{ A36 - I prefer to purchase expensive electrical appliances } & 0.414 \\
\hline \multicolumn{1}{|c|}{ Attribute Reduct 2 } & 0.329 \\
\hline \multicolumn{1}{|c|}{ Age } & 0.314 \\
\hline Income & 0.157 \\
\hline q6 - I prefer brands that offer a variety of models and appliances & Significance \\
\hline \multicolumn{1}{|c|}{0} \\
\hline Income & 0.231 \\
\hline Age & 0.221 \\
\hline q6 - I prefer brands that offer a variety of models and appliances & 0.125 \\
\hline q24 - I prefer to purchase the electrical appliances in response to opinion leaders & 0.125 \\
\hline q27 - I prefer to purchase electrical appliance that have specific color and shape & 0.106 \\
\hline
\end{tabular}

Source: own elaboration

On the basis of the results, the factor of approximation quality gamma, was calculated. It informs about what percentage of the analysed examples and conditional attributes allow determining certain rules. Approximation quality of the set $\mathrm{F}$ is expressed by the following formula:

$$
\gamma_{\tilde{Q}}(F)=\frac{\operatorname{card}^{\left(\operatorname{Pos}_{\tilde{Q}}(F)\right)}}{\operatorname{card}(U)}
$$

where the numerator includes the number of examples in the positive region of the set, and the denominator includes the number of examples in the whole universe of the set. In this case the value of gamma was 0.97, which means that on the basis of $97 \%$ of the examples gathered in the table, we can obtain results, which 
are in $100 \%$ certain. As a result of the further analyses two decision tables were made, containing: 64 rules describing the purchasing preferences of women and 99 rules describing the purchasing preferences of men. In the next step thesimilar rules were simplified and the rules applicable to the biggest number of cases were chosen (Table 5).

The attributes and the chosen rules of a decision algorithm

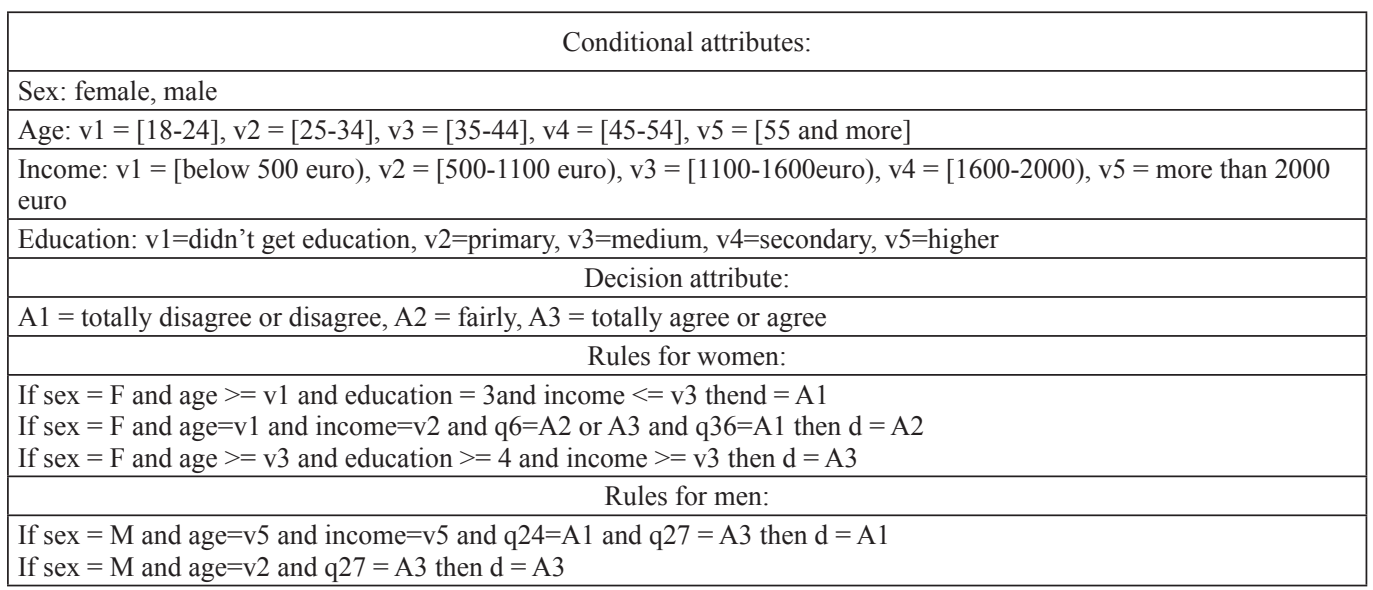

Source: own elaboration

The thoughts presented in the article allow to formulate a conclusion that in Iraq advertising attractiveness has a significant influence on the decisions concerning the choice and purchase of electrical home appliances made by women aged over 45 , with at least secondary education and high or very high income. Such people willingly buy appliances that are advertised.

Another conclusion is that for women aged over 35, who ended their education in the middle school and have an income below 1600 euro advertising attractiveness does not matter in the purchase decisions concerning the purchase of electrical appliances.

A similar situation occurs in the case of young women (aged from 18 to 24). Although this group of women prefers expensive home appliances, due to their low income they do not buy them and as a result do not pay any attention to the advertisements of such products (attractiveness of this adverts has no significance for them, they are indifferent to them).

In the case of men, aged over 45, having income above 2000 euro, their purchase decisions in purchase of electrical appliances are influences not only by advertising attractiveness but also by recommendations and suggestions of opinion leaders. Whereas for men aged from 24 to 35, apart from advertising attractiveness, it is also significant to have a possibility to buy a particular appliance in a concrete colour or shape.

\section{CONCLUSION}

This research contributes to the understanding of the consumer's buying behaviour in the electrical appliances market. The research problem was to study the influence of advertising attractiveness on the pur- 
chase decisions of women and men. But for properly organised surveys, it was possible to gather appropriate data, which was applied to generation of the rules of consumers' behaviour using the theory of rough set.

Research shows that even in the same group of customers, differences abound that make marketing to men and women another factor to consider. These differences require that the company define their target marketas men, women or both. They must define the market in order to better understand how to communicateeffectively with them. The companies need to focus on how the markets differ between men and women. It is vital that a company considers how each gender will perceive theirmarketing message. These perceptions determine if the potential customer will even consider the product in apurchase decision (Kraft and Weber, 2012).

\section{FUTHER RESEARCH}

The analysis, described in the article, helped authors to identify several promising directions for future research. The primary goal of this future research will be to develop methodological bases for the consumer's behavior analysis using Multi-Agent Based Simulation (MABS) and simulation tests using the developed methodology. As a result of the research, they plan to develop a computer simulation model that will allow to investigate male and female consumer behavior. The simulation model of the electric appliances market will be elaborated with a multi-agent approach.

\section{REFERENCES}

Abideen, Z. U., Saleem, S. (2011), Effective advertising and its influence on consumer buying behavior, European Journal of Business and Management, Vol. 3, No 3, pp. 55-65, available at: http://iiste.org/Journals/index.php/EJBM/article/viewFile/268/152 (access: 11.12.2013).

Altkorn, J. (1998), Podstawy marketingu, Kraków: Instytut Marketingu.

Ayanwale, A. B., Alimi, T., Ayanbimipe, M. A. (2005), The Influence of Advertising on Consumer Brand Preference, Journal of Social Science, Vol. 10(1), pp. 9-16.

Bae, S., Lee, T. (2011), Gender differences in consumers' perception of online consumer reviews, Electronic Commerce Research, Vol. 11(2), pp. 201-214, doi: 10.1007/s10660-010-9072-y.

Baker, A. (2012), Gender Differences in Decision Making, available at: www.decision-makingconfidence (access: 10.09.2012).

Bakshi, S. (2012), Impact of Gender on Consumer Purchase Behaviour, Abhinav National Monthly Refereed Journal of Research in Commerce \& Management, Vol. 1(9), pp. 1-8, available at: http://www.abhinavjournal.com/images/ Commerce_\&_Management/Sep12/1.pdf (access: 11.12.2013).

Belch, M. A., Willis, L. A. (2002), Family decision at the turn of the century: has the changing structure of households impacted the family decision-making process?, Journal of Consumer Behaviour, Vol. 2(2), pp. 111-124.

Bovee, L. C., Thill, V. J., Dovel, G. P., Wood, M. B. (1995), Advertising Excellence, McGraw Hill.

Burns, R. (2000), Introduction to Research Methods, 4th edn., London: Sage, doi:10.1332/030557393782453916.

Bussey, K., Bandura, A. (1999), Social cognitive theory of gender development and differentiation, Psychological Review, Vol. 106, pp. 676-713.

Crow, S. M., Fok, L. Y., Hartman, S. J., Payne, D. M. (1991), Gender and values: What is the impact on decision making? Sex Roles, Vol. 25, pp. 255-268.

Cui, N. (2009), A Rough-Set Based Approach to Predict Consumers' Brand Preference, International Workshop on Intelligent Systems and Applications, Wuhan, doi:10.1109/IWISA.2009.5072671. 
Davis, H. L., Rigaux, B. P. (1974), Perception of Marital Roles in Decision Processes, Journal of Consumer Research, Vol. 1, pp. 51-62.

Fu1, J.-R. and Chen, J. H. F. (2012), An Investigation of Factors that Influence Blog Advertising Effectiveness, International Journal of Electronic Business Management, Vol. 10, No. 3, pp. 194-203.

Furaiji, F., Łatuszyńska, M., Wawrzyniak, A. (2012), An Empirical Study of the Factors influencing Consumer Behaviour in the Electric Appliances Market, Contemporary Economics, Vol. 6(3), pp. 76-86, doi: 10.5709/ce.1897-9254.52.

Furaiji, F., Wąsikowska, B. (2012), Badanie preferencji zakupowych kobiet i mężczyzn metodą zbiorów przybliżonych, in: Zachowania konsumenckie - badania, uwarunkowania różnice, E. Rudawska, E. Frąckiewicz (eds.), Handel Wewnętrzny, Vol. I, pp. 26-35.

Gill, S., Stockard, J., Johnson, M., Williams, S. (1987), Measuring gender differences: The expressive dimension and critique of androgyny scales, Sex Roles, Vol. 17, pp. 375-400.

Goldsmith, R. E., Lafferty, B. A. (2002), Consumer response to websites \& their influence on advertising effectiveness. Internet research, Journal of Electronic Networking Application and Policy, Vol. 12(4), pp. 318-328.

Haas, A. (1979), Male and female spoken language differences: Stereotypes and evidence, Psychological Bulletin, Vol. 86(3), pp. 616-626, doi: 10.1037/0033-2909.86.3.616.

Hatala, R., Case, S. M. (2000), Examining the influence of gender on medical students' decision making, Journal of Women's Health and Gender Based Medicine, Vol. 9, pp. 617-623.

Hawkins, K., Power, Ch. B. (1999), Gender differences in questions asked during small decision-making group discussions, Small Group Research, Vol. 30, pp. 235-256.

Hyuang, C. (2010), 4 G Mobile phone consumer preference predictions by using the Rough Set Theory and flow graphs, Phuket, Tahailand: Technology Management for Global Economic Growth (PICMET).

Kaczmarczyk, S. (2003), Badania marketingowe. Metody i techniki, Warszawa: PWE.

Kardes, F.R., Cline, T.W., Cronley, M.L. (2011), Consumer Behavior. Science and Practice, South-Western, Cengage Learning.

Keegan, W., Moriarty, S., Duncan, T. (1992), Marketing, Englewood Cliffs, New Jersey: Prentice-Hall.

Kędzior, Z. et al. (2005), Badania rynku. Metody, zastosowania, Warszawa: PWE.

Komorowski, J., Pawlak, Z., Polkowski, L., Skowron, A. (1999), Rough sets: A tutorial, in: Rough fuzzy hybridization: A new trend in decision making, S.K. Pal and A. Skowron (eds.), Singapore: Springer-Verlag, pp. 3-98.

Kotler, P. (1994), Marketing. Analiza, planowanie, wdrażanie i kontrola, Warszawa: Gebethneri S-ka.

Kotler, P., Armstrong, G. (2007), Principles of Marketing, Upper Saddle River: Prentice Hall.

Kotler, P., Armstrong, G., Saunders, J., Wong, V. (2002), Marketing. Podręcznik europejski, Warszawa: PWE.

Kraft, H., Weber, J. M. (2012), A Look at Gender Differences and Marketing Implications, International Journal of Business and Social Science, Vol. 3, No. 21, pp. 247-253.

Lancaster, G. (2005), Research Methods in Management. A concise introduction to research in management and business consultancy. Jordan Hill, Oxford: Elsevier Butterworth-Heinemann Linacre House.

Liou, J., Tzeng, G. (2010), A Dominance-based Rough Set Approach to customer behavior in the airline market, Information Sciences, Vol. 180, Issue 11, pp. 2230-2238, doi:10.1016/j.ins.2010.01.025.

Meyers-Levy, J., Maheswaran, D. (1991), Exploring Males' and Females' Processing Strategies: When and Why Do Differences Occur in Consumers' Processing of Ad Claims, Journal of Consumer Research, Vol. 18, pp. 63-70.

Mokhlis, S., Salleh, H. S. (2009), Consumer Decision-Making Styles in Malaysia: An Exploratory Study of Gender Differences, European Journal of Social Sciences, Vol. 10, No 4, pp. 574-584.

Mrózek, A., Płonka, L. (1999), Analiza danych metodą zbiorów przybliżonych. Zastosowania w ekonomii, medycynie i sterowaniu, Warszawa: Akademicka Oficyna Wydawnicza PLJ.

Narayan, S. M., Corcoran-Perry, S. (1997), Line of reasoning as a representation of nurses' clinical decision making, Research in Nursing \& Health, Vol. 20, pp. 353-364. 
Niazi, G. S. K., Siddiqui, J., Shah, B. A., Hunjra, A. I. (2012), Effective advertising and its influence on consumer buying behavior, Information Management and Business Review, Vol. 4, No. 3, pp. 114-119.

Obaidat, M. (1995), Consumer Behavior, Cairo: The Future of Publishing and Distribution.

Ogino, A., Imamura, N., Kato, T. (2010), Modeling of human interest in products by observing behaviors of customer in a store, International Conference on Kansei Engineering and Emotion Research, Paris.

Orasanu, J., Connolly, T. (1993), The reinvention of decision making, in: Decision making in action: Models and methods, G. Klein, J. Orasanu, R. Calderwood and C. E. Zsambok (eds.), pp. 3-20, Norwood: Ablex.

Pawlak, Z. (1982), Rough sets, International Journal of Information and Computer Science, Vol. 341(11), pp. 344-356.

Pawlak, Z. (2004), Zbiory przybliżone nowa matematyczna metoda analizy danych, Miesięcznik Politechniki Warszawskiej, No 5/2004, p. 2.

Pfaff, D. (2010), Badania rynku. Jak pozyskiwać najistotniejsze dla firmy informacje marketingowe, Warszawa: Wyd. BC.edu.

Piegat, A. (2005/2006), Zastosowania zbiorów przybliżonych w ekonomii, lectures-Copie manuscript, Szczecin: Uniwersytet Szczeciński.

Putrevu, S. (2001), Exploring the Origins and Information Processing Differences Between Men and Women: Implications for Advertisers, Academy of Marketing Science Review [Online], available at: http://www.amsreview.org/articles/putrevu10-2001.pdf (access: 14.12.2012). Reprinted in the ICFAI Journal of Marketing Management, Vol. 2, No 1 (February, 2003), pp. 47-66.

Rudell, F., College, I. (1993), Gender Differences in Consumer Decision Making for Personal Computers: a Test of Hypotheses, in: GCB - Gender and Consumer Behavior, J. A. Costa (ed.), Vol. 2, Salt Lake City: Association for Consumer Research, pp. 1-16.

Rudnicki, L. (2012), Zachowania konsumentów na rynku, Warszawa: PWE.

Rutkowski, L. (2005), Metody i techniki sztucznej inteligencji, Warszawa: PWN.

Sanz de Acedo Lizárraga, M. L., Sanz de Acedo Baquedano, M. T., Cardelle-Elawar, M. (2007), Factors that affect decision making: gender and age differences, International Journal of Psychology and Psychological Therapy, Vol. 7, No 3, pp. 381-391.

Shibata, J. (2010), Analysis of unplanned purchase rule based on rough set, Computers and Industrial Engineering (CIE), Los Angeles, doi:10.1109/ICCIE.2010.5668266.

Solomon, M. R., Bamossy, G., Askegaard, S., Hogg, M. K. (2010), Consumer Behaviour: A European Perspective, Prentice Hall.

Stávková, J., Stejskal, L., Toufarová, Z. (2008), Factors Influencing Consumer Behavior, Agricultural Economics - Czech, 54, pp. 276-284.

Suleiman, A. (2000), Consumer Behavior between Theory and Practice, Cairo: The Future of Publishing and Distribution.

Venkatesh, V., Morris, M. G., Ackerman, P. L. (2000), A longitudinal field investigation of gender differences in individual technology adoption decision-making processes, Organizational Behavior and Human Decision Processes, Vol. 83, pp. 33-60.

Vindigni, G., Janssen, M.A., Jager, W. (2002), Organic food consumption. A multi-theoretical framework of consumer decision making, British Food Journal, Vol. 104, No. 8, pp. 624-642, doi:10.1108/00070700210425949.

Wąsikowska, B. (2007), Application of Rough Sets for Identification of Factors Determining Sold Production of Industry, Polish Journal of Environmental Studies, Vol. 16, No. 4A, pp. 372-375.

Wawrzyniak, A. (2010), Zastosowanie teorii zbiorów przybliżonych do identyfikacji reguł zachowań rynkowych na przykładzie urzędów gminnych województwa zachodniopomorskiego, Studia i Materiaty Polskiego Stowarzyszenia Zarządzania Wiedza, No 36, Bydgoszcz: Wyd. Polskie Stowarzyszenie Zarządzania Wiedzą.

Wiśniewska, A. (2005), Czynniki decydujące o wrażliwości konsumentów na markę, in: Instrumenty ksztaltowania wizerunku marki, A. Grzegorczyk (ed.), Warszawa: Wyższa Szkoła Promocji.

Wood, J. T. (1990), Gendered lives: Communication, gender, and culture, Belmont: Wadsworth. 